\title{
Academic letter on French Indochina War: Metaphors for strategic resilience
}

Simon Huston ${ }^{1}$

\begin{abstract}
Pandemics and military catastrophes illustrate systems fragility and impel strategic reflection. The French Indochina War (FIW) from 1946-1954 furnishes useful insights with resonance for current infectious, climatic, pollution, economic and security challenges. Five strategic themes structured an analysis of historical literature. The reasons for the French failure in 1954 involved fundamental regime illegitimacy, political equivocation, intelligence shortcomings, strategic and operational failures but also the determination, strength and adaptability of the Việt Minh (VM). In 1945, France had reoccupied Vietnam to re-assert its global credentials. Later, Cold War logic and American aid sustained "La sale guerre". However, the conflict merely delayed and bloodied an inevitable post-colonial regime shift. To maintain American aid flows yet retain French regional influence, the commander of the Expeditionary Corps, Henri Navarre, adopted an offensive stance. He sought to crush the VM, breathe life into the moribund French Union (L'Union française) and block Giáp's feints on Laos. In November 1954, he inserted a fortified camp at remote Diên Biên Phú (DBP). However, Navarre ignored the lessons of Hòa Bình (1950-51), Nghĩa Lộ (1951). He misread Nà Sản (1952) and underestimated VM capabilities. Operationally, the distance of DBP from Hanoi stretched the French aero-logistical system to its limits. Navarre also diverted resources to sideshow - Opération Atlante. Giáp realised Navarre had taken the bait and sealed off the besieged camp with five divisions, including an artillery one. On $13^{\text {th }}$ March, the VM attacked and conquered the garrison after 56 days on the evening of 7-8 ${ }^{\text {th }}$ May 1954. Navarre's gamble had spectacularly backfired. Militarily, the French Expeditionary Corps might have recovered even considering the bloodbath at Mang Yang Pass almost seven weeks later. However, the psychological blow unmasked regime financial and political bankruptcy. Power drained away to the Americans or the communists. Whilst French Indochina perpetuated an iniquitous social structure, tainted by racism, symbolic and physical violence, it arguably it also protected minorities, spurned dictatorship and transferred culture and technology.
\end{abstract}

The most striking finding that emerges from this investigation is the incredible transformation of the geography of Vietnam since 1948. Then, tigers and elephant roamed in jungles, $160 \mathrm{~km}$ North West of Saigon, near Phan Thiết. Today, suburbia encroaches on depleted coffee plantations and desiccated scrub. Aside from concerns over the long-term ecological trajectories under anthropogenic pressures in ostensibly communist or capitalist inspired systems and, notwithstanding today's very different context, the detailed investigation into aspects of the War provides strategic metaphors involving fiscal re-calibration, governance hierarchy or incentive regulations, hubristic corrections and ecological transformation.

\section{Keywords}

Strategy, foresight, French Indochina, RC4, Nà Sản, Diên Biên Phú, Vietnam, fiscal imbalance, hubris, ecological transformation

\footnotetext{
${ }^{1}$ Lecturer Accounting Coventry University UK
} 


\section{Introduction}

At the end of the Second World War in 1945, the French returned to Indochina but were warned by the Vietnamese Emperor, Bao Dai that, they needed to "renoncer à toute idée de rétablir ici la souveraineté ou une administration française" - renounce at any pretentions of re-establishing French rule or administration (Goscha, 2011, p. 52). This sound advice was ignored and, on $23^{\text {rd }}$ September 1945, in frenzied and confused street fighting, légionnaires, British Gurkhas and Japanese troops, gunned down rebels and reclaimed central Saïgon. In the southern suburb of Tam Dinh, a rampaging rebel mob took around 300 European and Eurasian civilians as hostages. Many were horribly mutilated, raped or murdered - probably around 40 but as many as 150 (Goscha, 2011, p. 202; Joint Chiefs of Staff, 2004, p.14). The rebels were disparate and disunited and the VM denied involvement in this massacre and implicated Binh Xuyen, a Vietnamese criminal brotherhood, whose leader they subsequently killed ${ }^{2}$ (Goscha, 2011, p. 202). The rebels retreated $30 \mathrm{~km}$ north to Thủ Dầu Một and, in an "atmosphere of violent ideological totalitarianism", the VM murdered dissenting nationalists (Ngo Van Xuyet, 2006). On the 5th October 1945, General Philippe Leclerc de Hauteclocque disembarked in Saïgon to command French forces that fanned out over Cochinchina (Southern Vietnam) but

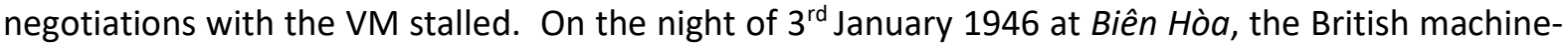
gunned hundreds of VM fighters assaulting their base. In the morning, it was clear that, for the time being at least, the anti-colonial rebellion had petered out and reactionary forces controlled Cochinchina. Despite Leclerc's recommendation to compromise with Hồ Chí Minh ${ }^{3}$ (HCM), French officials in Indochina, had no real interest in, "un accord équitable et durable" (Devillers, 1974, p. 297). For the colonials and the diaspora of anti-communist South Vietnamese, the VM were bad for business and likely to impose an intolerant, brutal and ruthless dictatorship. Colonial regime supporters knew that the communists would win any elections and, given frequent VM atrocities and documented prisoner maltreatment, justifiably feared the consequences (A.N.A.P.I., 2020; Bonnafous, 1985; Vann, 2010).

Allegedly, on $20^{\text {th }}$ November 1946 in Haïphong harbour, the VM opened fire on a moored colonial patrol ship. The incident provided a convenient pretext to abort elections and sparked the French or First Indochina War (FIW) (Garrett, 1967). A few days later, the cruiser Suffren shelled the port and killed around 6,000 Vietnamese (D.G.S.E, 2014; Garrett, 1967). Less than a month later, on $19^{\text {th }}$ December at 20:00, insurgents blew-up Hanoi's power plant and plunged the metropolis into darkness. The signal launched planned attacks by Võ Nguyên Giáp's rebels on French military outposts (ibid. 1967). Over the next 60 days battle raged but, eventually, French superior firepower and technology gradually snuffed out pockets of resistance. HCM fled 76 miles $(122 \mathrm{~km})$ north into the mountains near Bắc Kạn (D.G.S.E, 2014).

Seven and a half years later, on the night of 08th May 1954, La Sale Guerre (Dirty War) climaxed when the VM overran the residual Corps Expéditionnaire Français d'Extrême-Orient (C.E.F.E.O.) strongpoint (Isabelle) at DBP. On 15 th May 1955, within a year of this defeat but almost a decade since the first firefights in summer 1945, the last French ship sailed from Haïphong. The conflict damaged La Quatrième République. Its legacy included debts, widows, invalids and political disarray that fuelled two further conflicts. The Algerian and subsequent Vietnamese wars were both nasty, littered with atrocities and traumatic for France and America. Yet, notwithstanding "les errements stratégiques", including the disastrous retreat along Route Coloniale 4 in the 1950's and DBP, the Hexagons' elite colonial troops fought bravely and restored French military pride (Demélas, 2016, cover; Fogarty, 2014; Garrett, 1967). The French entanglement in Indochina bequeathed architecture, infrastructure and a contested cultural legacy (Norindr, 1996). An evaluation of the seminal colonial conflict begins

\footnotetext{
${ }^{2}$ He was ordered to shoot himself

${ }^{3}$ Alias Nguyễn Ái Quốc (1890-1969), also known as, "Celui qui éclaire”
} 
with a compte rendu of the FIW's cost in blood and treasure, well-documented, among others by Bodin (2003) and Tertrais (2002).

\section{Synthesis}

By 1953, France had abandoned the idea of winning the War and merely sought to retain Vietnam within a symbolic French Union. If they had only kept their word to HCM in 1945, around 250,000 young men could have lived, more than this number spared from debilitating injuries and roughly, the equivalent of $\$ 156 \mathrm{bn}^{4}$ spent more fruitfully (2020 equivalent to around 22 aircraft carriers). For Bloomer (1991, p IX) "the French heaped mistake upon miscalculation to create a disaster" and their infested chain of command spawned "operational and strategic blundering which staunch bravery by the fighting men could not overcome". Arguably, the remote strategic and military considerations of United States, the Soviet Union and China determined the FIW's end game. Ironically, after Vietnam finally gained independence in 1975, the Communists eventually abandoned collectivist agriculture, freed up markets and encouraged foreign investment. In the early 1990s, $91.8 \%$ of all rural households owned land but a decade later, in 2010, 22.5\% were landless. Some argue that Vietnam now runs an exploitative sweatshop economy and has ended up with the worst of possible worlds, an "authoritarian socialist state and the unfettered ideology of neoliberalism; the two combining to strip Vietnam's people of their money and their rights while a tiny elite fills its pockets and hides behind the rhetoric of the revolution"(Davies, 2015). Glewwe (2000) is less sceptical. The upshot though is that the French War led to the American one that, again, uselessly spilt gallons of blood, squandered untold treasure ${ }^{5}$ and poisoned 4.5 million hectares of forest, representing $14.5 \%$ of Vietnam's land $\operatorname{area}^{6}$ (Von Meding \& Hang Thaï, 2017).

The investigation into the 1954 French defeat generates six provisional conclusions. First, an anticolonial paradigm shift undermined their position and legitimised the Vietnamese right to genuine self-determination. Second, they underestimated their ruthless and competent enemy, backed by China. In January 1953, the VM promise of land reform helped mobilise 200,000 porters. Third, metropolitan political drift in Paris was debilitating for the French. Fourth, Navarre made a serious strategic military blunder by establishing a retrenched camp without adequate aerial logistic infrastructure. Fifth, Operation Atlante was a sideshow that distracted C.E.F.E.O. when its focus should have been on an early breakout or the evacuation of trapped pocket at DBP. The sixth finding is that a sequence of tactical errors compounded the Expeditionary Corps strategic imbroglio. L'Union française did not reinforce its artillery at the besieged camp nor entrench it. Aerial bombardment of VM supply routes proved ineffective and neither could French planes destroy VM artillery positions camouflaged in the hills surrounding DBP. Tactical details aside, the fundamental reasons for French defeat were political ineptitude and military miscalculation.

\section{Contemporary resilience metaphors}

The conflict provides some useful metaphors to help counter paradigm myopia in the Anthropocene. While many of the French colonials were reluctant admit that the War was unjust and unsustainable so too, today, the financial system in contemporary rentier, extractive, distraction or surveillance capitalism fails to distinguish value from price and needs calibrating and re-purposing (Acemoglu \& Robinson, 2012; Carney, 2020; Chamorro-Premuzic, 2014; Sadowski, 2020; Zuboff, 2019). The current

\footnotetext{
${ }^{4}(7.7 / .554) * 11$ (see s1.2)

5 \$141bn (1961-1975) (New York Times, 1975) but this baseline excludes interest, allies assistance or pension so perhaps $\$ 300$ bn is more realistic figure then. When inflated, baseline Vietnam War cost 1965-1975 at constant FY2011 prices becomes $\$ 738$ billion (Daggett, 2010)

${ }^{6}$ Total VN land area $=310,070$ sq. km. 1 ha $=0.01$ sq. km so $45,000 / 310,070$ (Central Intellingence Agency, 2020)
} 
system concentrates power in unelected monopolies that mine data or obfuscate to extract rents. Accounting or financial reporting systems tend to obscure, if not muzzle, multi-criteria sustainability or inclusivity performance data on, for example, effective tax rates, tonnes carbon, plastic or e-waste produced or ratio of directors to workers pay. Certainly, little attention is paid to biodiversity or extinction (Jill \& Warren, 2020). The current COVID crisis and threat of climate catastrophe highlight the limits of individualism, populism and short-term financial orientations. Alternative strategies involve redressing obvious system defects and aligning economic activities towards resilience. One system malignancy is regressive tax injustice, stoked by decades of emasculated free market ideology that fuelled inequality. The second disease is meritocratic or financial reporting hubris (Sandel, 2020) that masks an immense industry of self-promotion or cunning fiscal evasion and misinformation (Zucman \& Saez, 2020).

Once policy levers have extirpated the tumours of fiscal imbalance and reporting hubris, incentives should orientate activities towards substantive or socially useful contributions. So, rather than PR gestures, or the production of, what Adam Smith disparagingly called "baubles"(Smith, 1759, p. 161), resources need to focus on redressing inequality, precarity and the environmental crisis. Adjustments to the fiscal system should dampen excessive rewards to land, capital or "patrimoine" [inherited wealth] and, instead, guide disbursements to fruitful industry or productive labour (Piketty, 2013; Zucman, 2020). It requires independent, high-calibre institutions that temper monopolistic proclivities, scrutinise productive or consumptive conditionality and foster dignity for all citizens. Customs, rule of law and innovation restrain utopian design aspirations though as continuous interventions for a patterned distribution (utopia) raise the perennial question of "sed quis custodiet ipsos custodes?" [...but who will watch the watchers themselves?] (Juvenal, 115 C.E., lines 347-8). Patterned resource allocation are prone to autocracy, if not tyranny, but alternative entitlement or principled systems need tuning (Kaufman, 2004).

The final metaphor from the study on the FIW comes from the dead on both sides -Baudelaire's (1857, p.58), "martyrs d'un chemain mauvais" [martyrs of a misguided route] who impel reflection on current directions and perhaps some re-calibration towards solidarity in sustainable communities. Notwithstanding system fiscal, social or ecological adjustments, the Technosphere's 30 trillion tonnes anthropogenic legacy remains a concern (Zalasiewicz et al., 2016). Every week, we pump transformed materials into the environment equivalent to the bodyweight of each human on the planet so that, shortly, the Technosphere's debris will exceed global living biomass (Elhacham et al., 2020). Like colonial French Indochina, the environmental (E), fiscal (S) and hubristic (G) or ESG status quo is unsustainable. 


\section{Brief glossary}

C.E.F.E.O.: Corps Expéditionnaire Français d'Extrême-Orient or French Expeditionary Force, around 185,000 men in 1954, supplemented by troops from the Associated States.

Diên Biên Phú (DBP): Entrenched camp in remote jungle valley, $456 \mathrm{~km}$ by road from Hanoi or $296 \mathrm{~km}$ by air (50-70 minutes in a Dakota). From $12^{\text {th }}$ March 1954 , the camp was pulverised by VM artillery from surrounding hills and overwhelmed on evening $07^{\text {th }}-08^{\text {th }}$ May 1954.

FIW: French Indochina War from 1946-1954.

Opération Atlante: Massive but unsuccessful amphibious and airborne operation to clear Central Highlands of VM, January-March 1954 but aborted in face of heavy casualties, including on February $17^{\text {th }}$ when VM 803 overran Groupe Mobile 100 at Dak Doa.

Nà Sản (1952): Entrenched camp 188km by air from Hanoi or 35-45 minutes by Dakota. General Salan flew in 11 battalions and 6 artillery batteries to thwart a VM attack.

Nghĩa Lộ (1951): Successful battle for French where paratroops dropped behind VM lines to disrupt an attack on a fortified jungle outpost.

RC4 (1950): Colonial Road 4 runs parallel with Chinese frontier in Tonkin. In 1950, the French retreated along it but the VM decimated them. Henceforth, Chinese supplies crossed the frontier virtually unhindered.

L'Union française: French Union coalition of France with the Associated States of Vietnam, Laos and Cambodia.

VM: Việt Minh or communist nationalists led by Hồ Chí Minh and backed by China.

\section{Bibliography}

A.N.A.P.I. (2020). Association Nationale des Anciens et Amis de I'Indochine. http://www.anapi.asso.fr/index.php/les-chiffres

Acemoglu, D., \& Robinson, J. (2012). Why nations fail: The origins of power, prosperity and poverty. Profile.

Baudelaire, C. (1857). Les fleurs du mal (1st ed.). Poulette Malassis.

Bloomer, H. (1991). An analysis of the French defeat at Dien Bien Phu. https://www.globalsecurity.org/military/library/report/1991/BHD.htm

Bodin, M. (2003). Le corps expéditionnaire Français à la veille de la Bataille de Diên Biên Phû. In Guerres mondiales et conflicts contemporains (pp. 11-27). Presses Universitaires de France. https://doi.org/10.3917/gmcc.211.0011

Bonnafous, R. (1985). Les prisonniers français dans les camps Viet minh 1945-1954. Ccentre d'Histoire militaire et d'études de défense nationale.

Carney, M. (2020). The Reith Lectures 2020: How we get what we value. BBC Radio 4; $\mathrm{BBC}$. https://www.bbc.co.uk/programmes/m000py8t

Central Intellingence Agency. (2020). CIA World factbook. https://www.cia.gov/library/publications/resources/the-world-factbook/geos/vm.html 
Chamorro-Premuzic, T. (2014, December 15). The distraction economy: how technology downgraded attention. The Guardian. https://www.theguardian.com/media-network/media-networkblog/2014/dec/15/distraction-economy-technology-downgraded-attention-facebook-tinder

D.G.S.E. (2014). DGSE in Indochine 1944-1954: De la seconde guerre mondiale à la guerre froide. Ministère Des Armées. https://www.defense.gouv.fr/dgse/tout-le-site/indochine

Daggett, S. (2010). Costs of Major U.S. Wars.

Davies, N. (2015, April 22). Vietnam 40 years on: how a communist victory gave way to capitalist corruption. The Guardian, Online edition. https://www.theguardian.com/news/2015/apr/22/vietnam-40-years-on-how-communistvictory-gave-way-to-capitalist-corruption

Demélas, M.-D. (2016). Parachutistes en Indochine. Vendémiaire.

Devillers, P. (1974). La fin d'une "guerre d'Indochine " (1954). Revue Française de Science Politique, 295-308. https://www.persee.fr/doc/rfsp_0035-2950_1974_num_24_2_418676

Elhacham, E., Ben-Uri, L., Grozovski, J., Bar-On, Y. M., \& Milo, R. (2020). Global human-made mass exceeds all living biomass. Nature. https://doi.org/10.1038/s41586-020-3010-5

Fogarty, M. (2014). Why did the French lose their Indochinese colonies? Australian Naval Institute. https://navalinstitute.com.au/why-did-the-french-lose-their-indochinese-colonies/

Garrett, C. W. (1967). In Search of Grandeur: France and Vietnam 1940-1946. The Review of Politics, 29(3), 303-323. http://www.jstor.org/stable/1405759

Glewwe, P. (2000). Are foreign-owned Businesses in Vietnam really sweatshops? Minesota Agricultural Economist, Summer(701), 1-8.

Goscha, C. E. (2011). Historical dictionary of the Indochina War (1945-1954): An international and interdisciplinary approach. Nias Press.

Jill, A., \& Warren, M. (2020). The Naturalist's Journals of Gilbert White: exploring the roots of accounting for biodiversity and extinction accounting. Accounting, Auditing \& Accountability Journal, 33(8), 1835-1870. https://doi.org/10.1108/AAAJ-03-2016-2450

Joint Chiefs of Staff. (2004). The Joint Chiefs of Staff and the First Indochina War 1947-1954.

Juvenal. (115 C.E.). Satires of Juvenal, Persius, Sulpicia, and Lucilius. In VI. http://www.thelatinlibrary.com/juvenal/6.shtml

Kaufman, A. (2004). The myth of the patterned principle: Rawls, Nozick and Eentitlements. Polity, 36(4), July 2004. https://doi.org/10.1086/POLv36n4ms3235402

New York Times. (1975, May 1). U.S. Spent \$141-Billion In Vietnam in 14 Years. New York Times. https://www.nytimes.com/1975/05/01/archives/us-spent-141billion-in-vietnam-in-14years.html

Ngo Van Xuyet. (2006). 1945: The Saigon commune. Libcom.Org. https://libcom.org/history/articles/saigon-commune-1945

Norindr, P. (1996). Phantasmatic Indochina. French colonial ideology in architecture, film and literature. Duke University Press. https://doi.org/10.2307/3685659

Piketty, T. (2013). Le Capital au XXIe siècle. Éditions du Seuil.

Sadowski, J. (2020). The Internet of landlords: Digital platforms and new mechanisms of rentier 
capitalism. Antipode, 52(2), 562-580. https://doi.org/https://doi.org/10.1111/anti.12595

Sandel, M. (2020). The tyranny of merit: What's become of the common good? Allen Lane.

Smith, A. (1759). The theory of moral sentiments. In S. M. Soares (Ed.), Philosophy (6th ed.). MetaLibri. https://doi.org/10.1017/S0031819100023536

Tertrais, H. (2002). La piastre et le fusil. Le coût de la guerre 1945-1954. C.H.E.F.F.

Vann, M. G. (2010). Caricaturing "The Colonial Good Life" in French Indochina. European Comic Art. https://doi.org/10.3828/eca.2.1.6

Von Meding, J., \& Hang Thai, T. . (2017). How U.S. chemical warfare in Vietnam unleashed an enduring disaster. Phys Org. https://phys.org/news/2017-10-chemical-warfare-vietnam-unleasheddisaster.html

Zalasiewicz, J., Williams, M., Waters, C. N., Barnosky, A. D., Palmesino, J., Rönnskog, A.-S., Edgeworth, M., Neal, C., Cearreta, A., Ellis, E. C., Grinevald, J., Haff, P., Ivar do Sul, J. A., Jeandel, C., Leinfelder, R., McNeill, J. R., Odada, E., Oreskes, N., Price, S. J., ... Wolfe, A. P. (2016). Scale and diversity of the physical technosphere: A geological perspective. The Anthropocene Review, 4(1), 9-22. https://doi.org/10.1177/2053019616677743

Zuboff, S. (2019). The age of surveillance capitalism: The fight for a human future at the new frontier of power. Public Affairs Books.

Zucman, G. (2020). Repenser l'impôt, avec Gabriel Zucman. France Culture. https://www.franceculture.fr/emissions/entendez-vous-leco/entendez-vous-leco-emission-dumercredi-30-decembre-2020

Zucman, G., \& Saez, E. (2020). Le triomphe de l'injustice - Richesse, évasion fiscale et démocratie. Éditions du Seuil. 